\title{
Morphology of glandular stomach (Ventriculus glandularis) and muscular stomach (Ventriculus muscularis) of the partrigde Rhynchotus rufescens
}

\author{
Morfologia do proventrículo gástrico (Ventriculus glandularis) e do ventrículo gástrico \\ (Ventriculus muscularis) de perdizes Rhynchotus rufescens
}

\author{
Juliana Regina Rossi ${ }^{1}$ Silvana Martinez Baraldi-Artoni ${ }^{2}$ Daniela Oliveira ${ }^{1}$ \\ Claudinei da Cruz ${ }^{3}$ Vanessa Sobue Franzo ${ }^{1}$ Alex Sagula $^{4}$
}

\section{ABSTRACT}

Twenty adult partridges Rhynchotus rufescens were used for morphologic and histological study. The materials destined to the morphologic study were collected and the lengths of the glandular stomach and of the muscular stomach were measured. For the histological study, fragments of the glandular stomach (gastric proventriculus, ventriculus glandularis) and of the muscular stomach (gastric ventriculus, ventriculus muscularis) were stained routinely with periodic acid-Schiff (PAS) and Masson's trichrome stain. Glandular stomach is prolonged, with a fusiform format toward craniocaudalis and for the left. It presents a mean length of $3.20 \mathrm{~cm}$ in the females and $3.65 \mathrm{~cm}$ in the males. Gastric proventriculus is composed by several lobes and glands. The mucosa is formed by a simple cubic epithelium, which is much folded. Muscular stomach has the format of a biconvex lens, with $4.30 \mathrm{~cm}$ and $4.35 \mathrm{~cm}$ of mean length for the females and male, respectively. The mucosa is formed by folds lined by columnar cells and the mucus that forms the cuticula. There are crypts in the base of the folds. Closely, there is a lamina propria and a thick smooth muscle layer, which is placed according to the format of the organ. A dense portion of connective tissue constitutes the serosa, mixed by some smooth muscle cells.

Key words: morphology, partridge, glandular stomach, muscular stomach.

RESUMO

Vinte perdizes Rhynchotus rufescens adultas foram utilizadas para estudo morfológico do proventrículo e ventrículo gástricos da perdiz Rhynchotus rufescens. Os materiais foram coletados e os comprimentos do proventrículo e do ventrículo gástricos foram avaliados. Para o estudo histológico, fragmentos dos estômagos foram corados pelas técnicas de ácido periódico de Schiff (PAS) e tricromo de Masson. O proventrículo gástrico é alongado, com formato fusiforme direcionado no sentido craniocaudalmente e para a esquerda, e apresenta um comprimento médio $3,20 \mathrm{~cm}$ nas fêmeas e $3,65 \mathrm{~cm}$ nos machos. Histologicamente, o proventrículo gástrico é composto por vários lobos e glândulas. A mucosa é formada por epitélio cúbico, sendo bastante pregueada. O ventrículo gástrico tem o formato de uma lente biconvexa, com comprimento médio de $4,30 \mathrm{~cm}$ nas fêmeas e $4,35 \mathrm{~cm}$ nos machos. A mucosa é formada por pregas revestidas por células cilíndricas e pelo muco formador da cutícula. Há criptas na base das pregas. Em seguida, há uma lâmina própria e uma espessa camada muscular lisa, que se encontra direcionada de acordo com o formato do ventrículo gástrico. A serosa é constituída por uma densa porção de tecido conjuntivo, entremeado por algumas células musculares lisas.

Palavras-chave: morfologia, perdiz, proventrículo gástrico, ventrículo gástrico.

\section{INTRODUCTION}

Stomach of the fowls is composed by two parts: the glandular portion, called gastric proventriculus (glandular stomach - Ventriculus glandularis) and the muscular portion, known as

\footnotetext{
${ }^{1}$ Faculdade de Ciências Agrárias e Veterinárias (FCAV), Universidade Estadual Paulista (UNESP), Jaboticabal, SP, Brasil.

${ }^{2}$ Departamento de Morfologia e Fisiologia Animal, FCAV, UNESP, 14883-900, Jaboticabal, SP, Brasil. E-mail: smbart@fcav.unesp.br. Author for correspondence.

${ }^{3}$ Centro de Aqüicultura da UNESP (CAUNESP), Jaboticabal, SP, Brasil.

${ }^{4}$ Centro Universitário de Araraquara (UNIARA), Jaboticabal, SP, Brasil.
} 
gastric ventriculus or gizzard (muscular stomach Ventriculus muscularis), which are separated by an isthmus or intermediate zone. The chicken stomach is at the left of the median line and it is dorsal to the liver. In carnivorous and piscivorous fowls that swallow big victuals very little distinction exists between the glandular and the muscular stomach (SISSON \& GROSSMAN, 1986; BAUMEL et al., 1993).

In the mucosal surface of the glandular stomach of the chicken, there are projections of several papillae, low and wide, on the lumen; the apex of each papilla opens up an exit duct of one of the composite glands, which function is digest protein (SISSON \& GROSSMAN, 1986). MELVIN\& REECE (1996) mention that the gastric proventriculus produces and liberates pepsinogen, hydrochloric acid and mucus. The distribution of these glands is in the whole glandular stomach in most of the fowls.

The wall organization of the fowl glandular stomach is according to the general pattern that typifies most of the digestive organs. Glands of the gastric proventriculus, however, are different from those found in the mammal species. The mucosa is excessively folded, forming flat folds separated for rifts or furrows. Mucous glands (simple tubular glands) open up in the bases of the furrows. Elevations of tunica muscularis (papillae) contain the openings of the exit ducts of the submucosa or proventriculus glands (BANKS, 1992).

Cuboidal cells form the epithelium of the mucosal layer. Those cells extend for the interior of the furrows. Lamina propria is typical and it contains numerous nodular lymphatic tissues, which are nodular or diffuse. An interrupted layer of guided fibers forms the muscularis mucosae longitudinally, and bunches are interdigited among the mucous glands. Submucosa is dislodged by the great and numerous submucosal glands, wich are compound, ramified or tubular. Due to the fowls gastric secretion to be similar to the mammals, it is admitted that these cells can secrete as much the products of the enzymatic secretion as the acids. Tunica muscularis is slightly modified and the inner longitudinal, circular and outer longitudinal layers are present. The tunica serosa is composed by connective tissue and a cuboidal cells layer(BANKS, 1992).

In relation to the gastric ventriculus, the body separates the two tapering ends, the saccus cranialis and saccus caudalis in chicken and bustards (SISSON \& GROSSMAN, 1986; BAILEY et al., 1997). NICKEL et al. (1977) describes that in the vegetarian fowls, the muscular stomach is considered as a masticator organ. The gastric ventriculus is to the left of the median line and it can be touched immediately caudal to the breastbone, as a firm mass. It presents an extremely thick wall, internally lined for a simple columnar epithelium. Tubulous glands open in crypts of the epithelium. The inner aspect of the Ventriculus muscularis is lined by a hardened membrane, the cuticula gastrica as BAILEY et al. (1997) described in bustards. BENNETT \& COBB (1969) demonstrated that the muscular stomach smooth muscle is mainly disposed in crossed bunches or layers, separated by connective tissue, in relation to the other visceral muscles. The musculature of this organ can generate one of the greatest tensions already registered in smooth musculature, according to GEORGE et al. (1998).

BANKS (1992) stated that the lumenal surface of chicken muscular stomach is lined by a proteinaceous substance similar to keratin produced by mucous glands. GEORGE et al. (1998) related that glands produce the material of the hardened membrane of the gizzard, called koilin. A layer of elastic and collagen fibers is observed surrounding the mucosae, constituting the compact stratum, and externally is limited with the submucosa. Tunica muscularis of the muscular stomach presents a very developed inner circular layer, and a narrow outer longitudinal layer. Outer the tunica muscularis, there is connective tissue lined for a cuboidal cell layer, characterizing the serosa.

The purpose of this paper was to study the morphology of the glandular and the muscular stomach of the partridge Rhynchotus rufescens.

\section{MATERIAL AND METHODS}

Twenty adult partridges Rhynchotus rufescens were used (10 males and 10 females). The fowls were euthanased with ethyl ether and after the laparotomy and uncover the esternal breastplate, organs were documented "in loco" and later partial evisceration of the alimentary tract was made. The materials destined to the morphologic study were collected and the lengths of the gastric proventriculus and ventriculus were measured and placed in a $10 \%$ formalin solution.

For the histological study, fragments of the stomachs were immersed in Bouin for 24 hours and later submitted to the dehydration process with alcohol and embedded in Paraplast (Merk $\left.{ }^{\circledR}\right)$. Histologic sections of $7 \mu \mathrm{m}$ of thickness were obtained and they were stained routinely with periodic acid-Schiff (PAS) and Masson's trichrome stain. The sections were documented in Olympus microscope, model BX50, analyzed and described. The anatomical nomenclature 
used was based on Nomina Anatomica Avium (BAUMEL et al., 1993) whenever possible.

After obtaining the data, variance analysis and qui-square test (5\% significance) was calculated using the software "SAS" (1999) for comparison among the sexes.

\section{RESULTS AND DISCUSSION}

Avian stomach is a smooth muscular organ, located between the esophagus and the intestine, and it is constituted of two different portions: glandular and muscular stomach (SUGANUMA et al., 1981; DYCE et al., 1996; BAILEY et al., 1997; BACHA \& BACHA, 2000).

The glandular portion denominated of gastric proventriculus, in partridge, is prolonged, with a fusiform format toward craniocaudalis and to the left. It presents a mean length of $3.20 \mathrm{~cm}$ in the females and $3.65 \mathrm{~cm}$ in the males (Figure 1). It was not observed significant differences among the sexes of Rhynchotus rufescens, in contrast to the observations of BAILEY et al. (1997) in bustard glandular stomach.

According to MACARI et al. (1994), the avian Ventriculus glandularis is a structure located between the lower esophagus and the gastric ventriculus, lined by a glandular mucosa with secretory function (the gastric secretory glands), as found in partridge (Figures 2A and 2B). Rostrally, there is not a clear division between the partridge glandular stomach and the lower esophagus, but in the caudal portion the gastric proventriculus separates from the muscular stomach through the isthmus, as shown by MACARI et al. (1994) in chicken and BAILEY et al. (1997) in bustards.

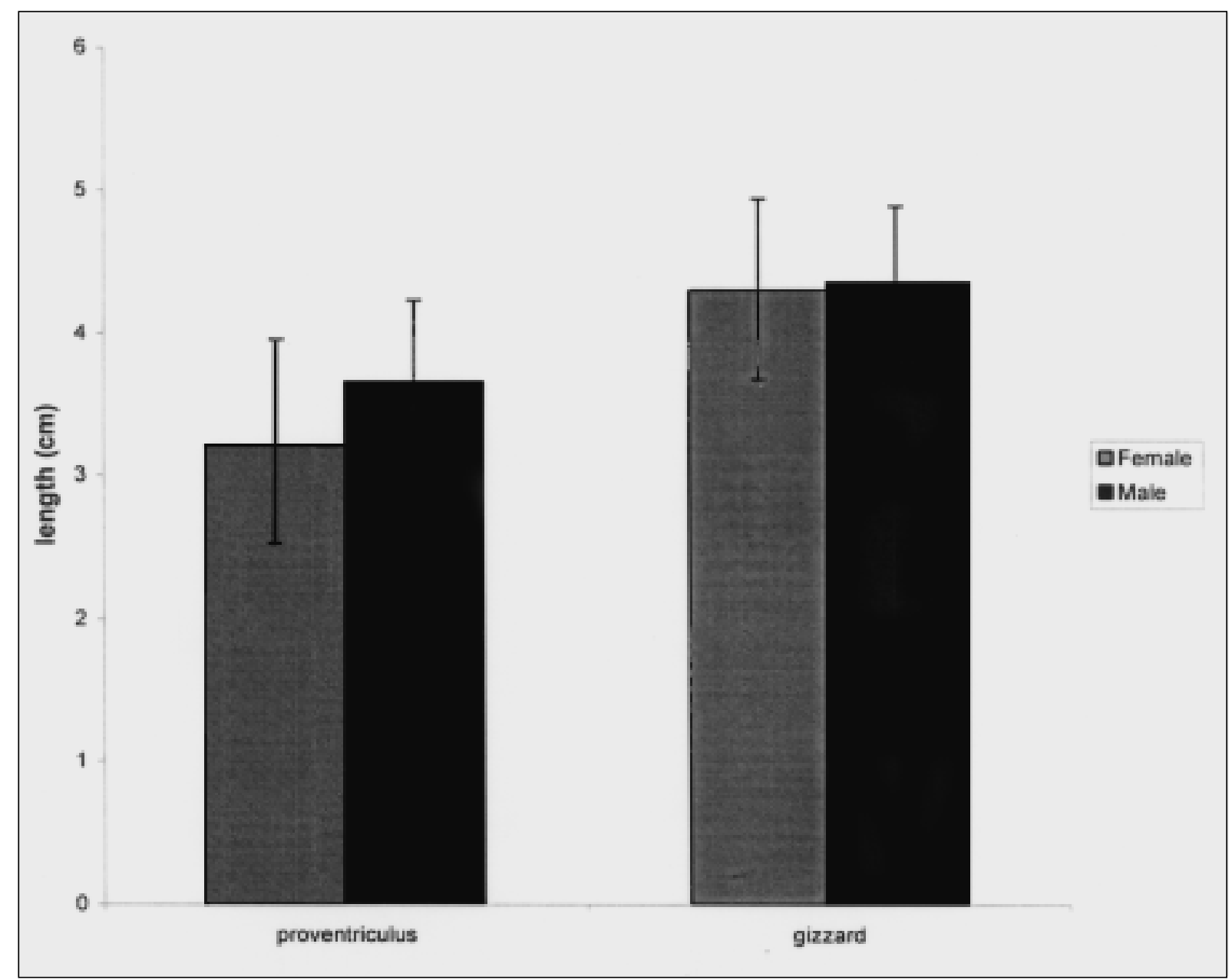

Figure 1 - Variation of mean values \pm standard deviation of glandular and muscular stomach lengths $(\mathrm{cm})$ of females and males partridge Rhynchotus rufescens.

Ciência Rural, v.35, n.6, nov-dez, 2005. 


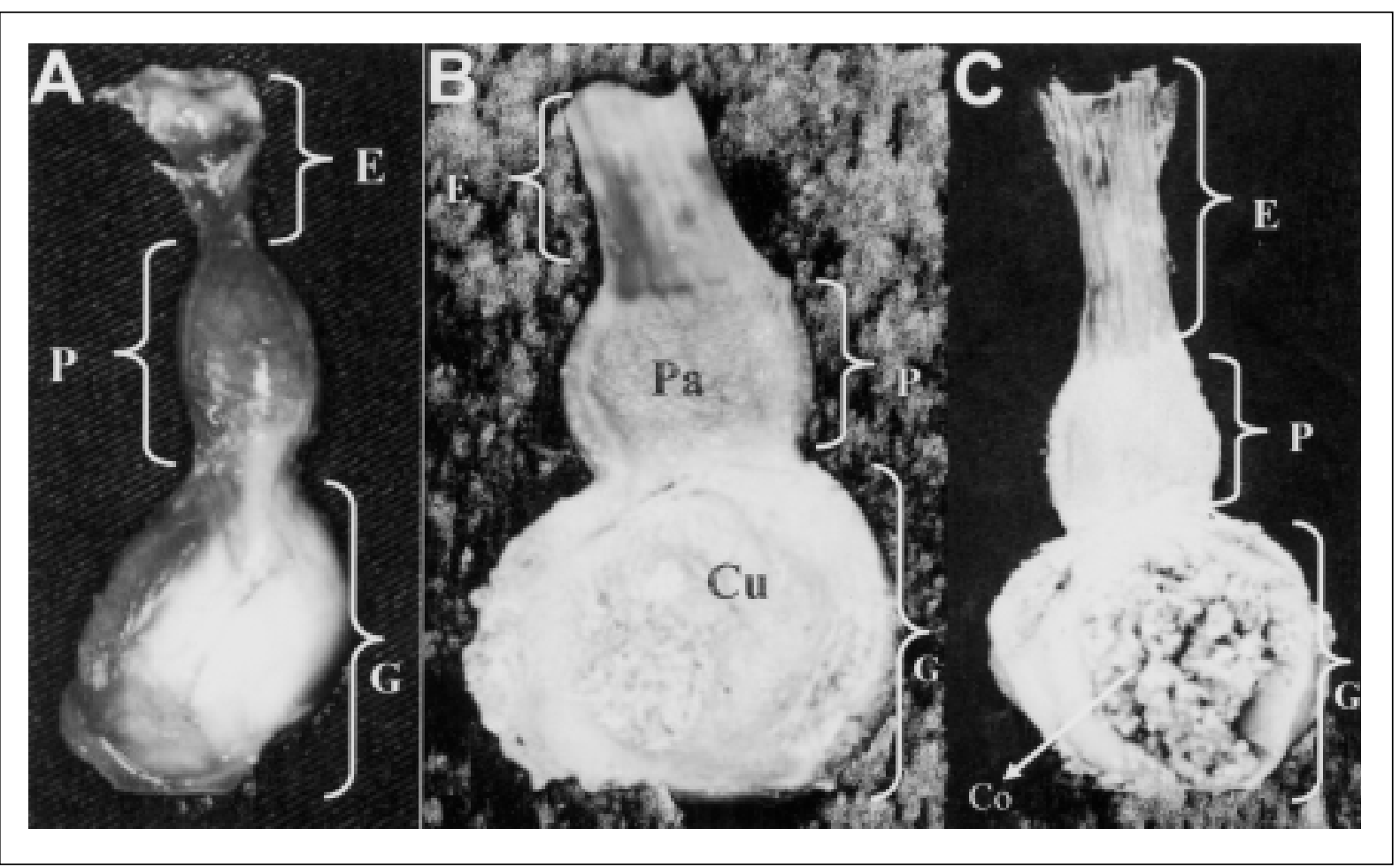

Figure 2 - A - Dorsal view of partridge esophagus (E), gastric proventriculus (P) and gastric ventriculus (G). B - Partridge opened esophagus $(\mathrm{E})$, gastric proventriculus $(\mathrm{P})$ and gastric ventriculus $(\mathrm{G})$. Papillae $(\mathrm{Pa})$ and the yellowish cuticula $(\mathrm{Cu}) . \mathrm{C}$ Partridge opened esophagus (E), gastric proventriculus (P) and gastric ventriculus (G). Inside the muscular stomach there is content $(\mathrm{Co})$ of feed, grass and particles of stones.

Mucosa of Ventriculus glandularis of the partridge has glands whose ducts open up in numerous macroscopic elevations, denominated papillae (Figure 2B) as in chicken (TURK, 1982; DYCE et al., 1996) and bustards (BAILEY et al., 1997).

Several lobes form the partridge glandular stomach and contain the proventriculus glands. They are divided by septa of connective tissue (Figures 3A, $3 \mathrm{C}$ and $3 \mathrm{D}$ ). These glands produce a secretion and throw it in the lumen of each lobe. The secretion is expelled for the glandular stomach lumen through ducts that are toward the base of the mucosa folds. The mucosa is formed by a simple cubic epithelium that is much folded (Figures 3C and 3D). The organ is involved by an inner longitudinal musculature and an outer circular layer, which is surrounded by serosa (Figures 3A and 3B).

Gastric ventriculus contains the acids and enzymes secreted in the gastric proventriculus (TURK, 1982; MACARI et al., 1994). Muscular stomach of partridge is between the proventriculus and the intestine, lying in the left dorsal and ventral regions of the thoracoabdominal cavity, as well as BAILEY et al. (1997) have described in bustards. In partridge, the muscular stomach presents the format of a biconvex lens, with $4.30 \mathrm{~cm}$ and $4.35 \mathrm{~cm}$ of mean length for the females and male, respectively (Figure 1). There were not differences among the sexes of Rhynchotus rufescens, in contrast to the data of BAILEY et al. (1997). CHIKILIAN \& DE SPERONI (1996) observed that the muscular stomach of Nothura maculosa and Nothoprocta cinerascens have round format, and in Crypturellus tataupa it presents an oval format.

Gastric ventriculus is constituted by four semiautonomous muscles, two thick and dark colored, the caudodorsalis and the cranioventralis, and two with fine thickness and clear colored, the craniodorsalis and the caudoventralis, that are responsible to crush the victuals ingested, according to the results of BAILEY et al. (1997). A white and brilliant sheet is observed in the center of the gastric ventriculus of partridge characterizing a tendinous connective tissue (Figure 2A), also found in chicken (TURK, 1982; DYCE et al., 1996).

The mucosa of the Rhynchotus rufescens muscular stomach is formed by folds lined by columnar cells and the mucus that forms the cuticula, which is proteinlike and presents projections to the lumen (Figure 4A). Crypts are in the base of the folds (Figure 4A) and closely, 


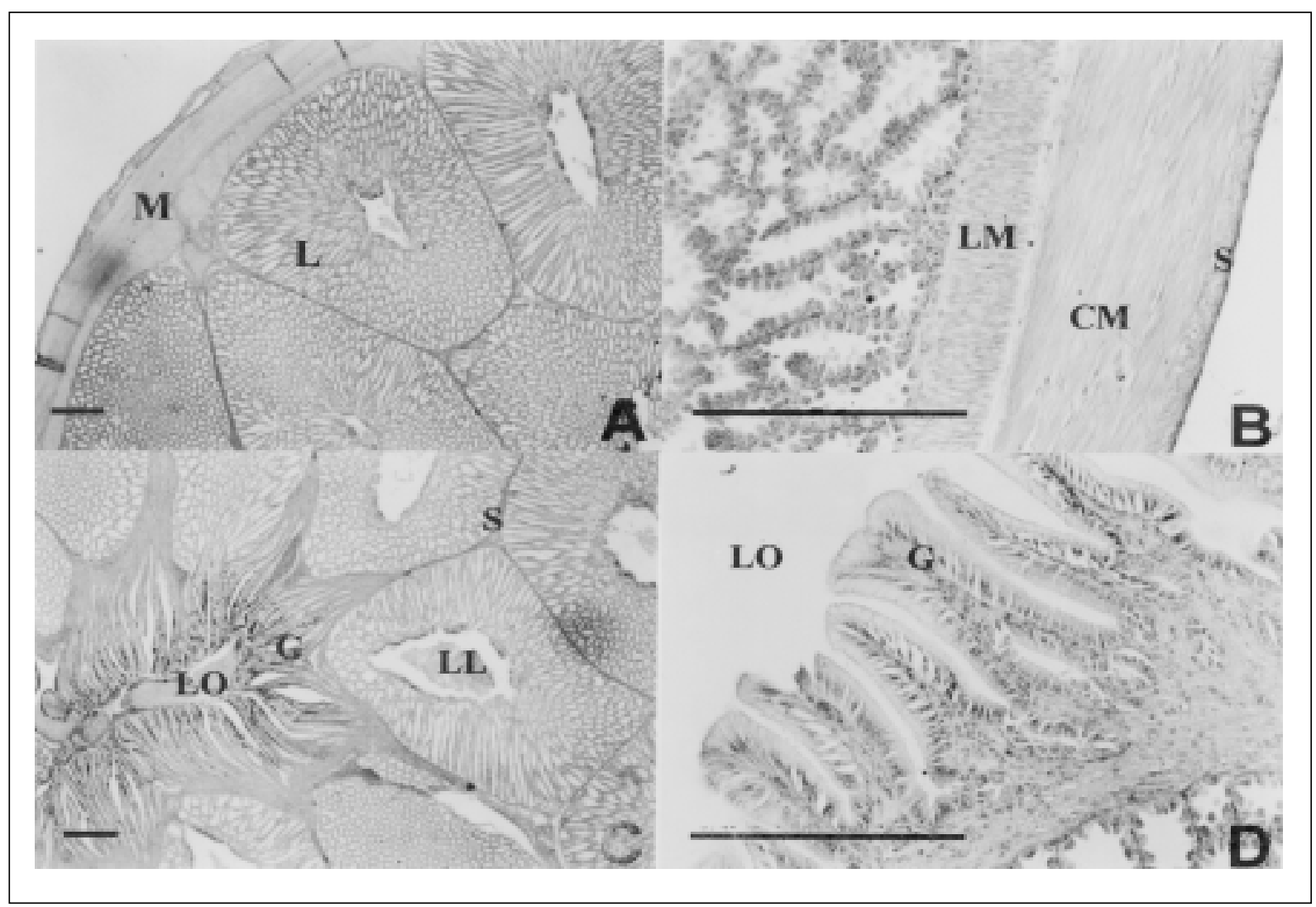

Figure 3 - A - Transversal section of partridge glandular stomach illustrating the relationship between the lobules (L) and the musculature (M) which holds the organ. PAS. B - Detail of the partridge gastric proventriculus musculature. An inner longitudinal muscle layer (LM) and outer circular muscle layer (CM) are shown surrounded by serosa (S). Masson's trichrome stain. C - Transversal section of partridge gastric proventriculus. The mucous membrane presents glands (G) that are expanded to the lumen of the organ (LO). The glandular parenchima is divided by septs (S). Lobule lumen (LL). PAS. D Detail of proventriculus mucosa. There are glands (G) that are expanded to the lumen of the organ (LO). Masson's trichrome stain. Barr $=25 \mu \mathrm{m}$.

there are a lamina propria and a thick smooth muscle layer, which is placed according to the format of the organ. A dense portion of connective tissue constitutes the serosa, mixed by some smooth muscle cells (Figure 4B).

The inner aspect of the muscular stomach of the partridge is lined by a fine cuticula gastrica, with a yellowish color, also observed by SUGANUMA et al. (1981) in wild fowls. DYCE et al. (1996) described that mucosa glands secretion solidifies in the surface and form the cuticula (Figure 2B).

In the content of the muscular stomach of Rhynchotus rufescens could be found small solids, as grains of sand or even small stones (Figure 2C). In birds that eat seeds, the strong contractions of the organ triturate the food with the help of ingested grains, activity that can be compared to the masticatory function of the teeth in mammals (DYCE et al., 1996). The occurrence of stomach impaction is possible in the glandular and muscular stomach of ostriches, associated with high mortality, as described by SATO et al. (1994).

\section{CONCLUSION}

Gastric proventriculus is prolonged, with a fusiform format toward craniocaudalis and for the left. It is composed by several lobes and glands. The mucosa is formed by a simple cubic epithelium, which is much folded.

Gastric ventriculus has the format of a biconvex lens. The mucosa is formed by folds lined by columnar cells and the mucus that forms the cuticula. There are crypts in the base of the folds. Closely, there are a lamina propria and a thick smooth muscle layer, which is placed according to the format of the organ. A dense portion of connective tissue constitutes the serosa, mixed by some smooth muscle cells. Both stomachs are longer in males than in females. 


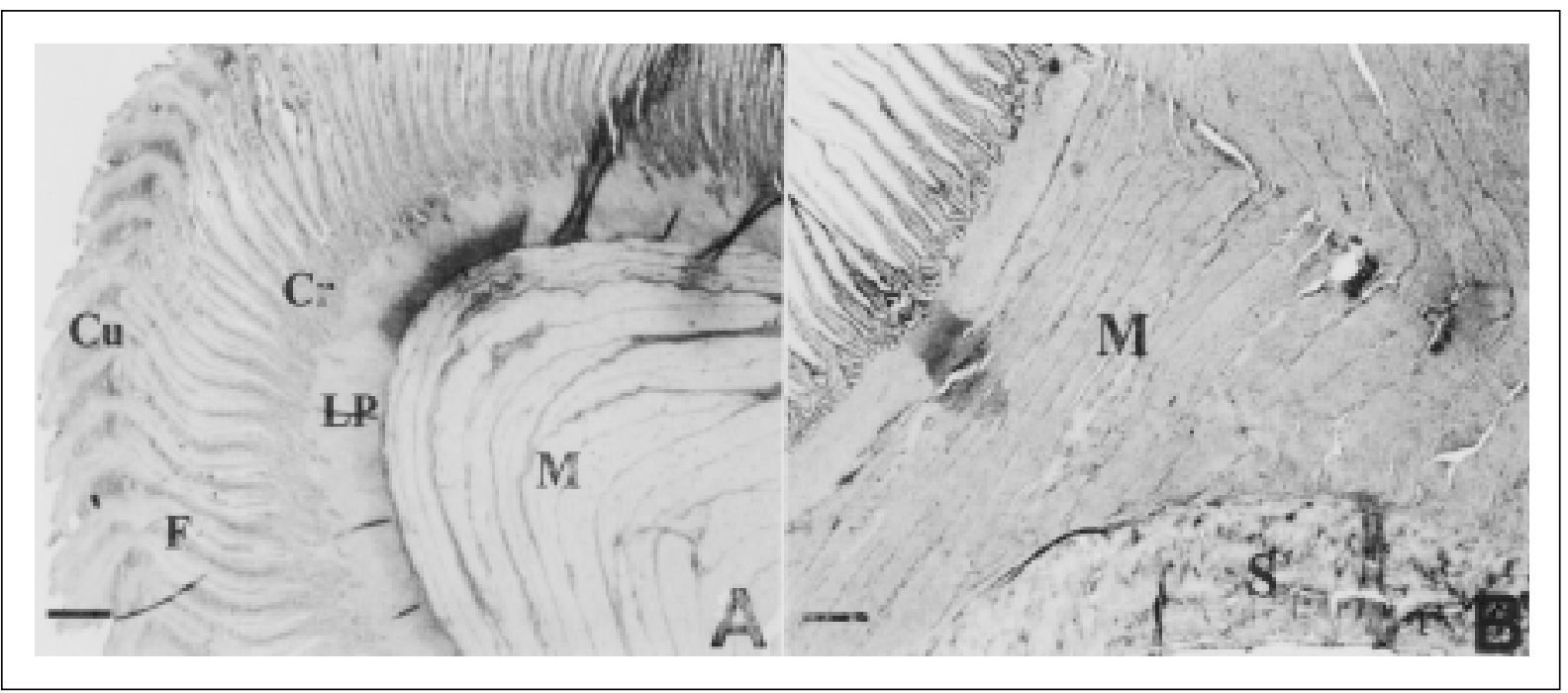

Figure 4 - A - Transversal section of the partridge muscular stomach. Mucosa presents folds (F) that are expanded in the mucus that form the cuticula $(\mathrm{Cu})$. The base of the folds constitutes the crypts $(\mathrm{Cr})$. The muscle layer $(\mathrm{M})$ is below the lamina propria (LP). PAS. B - Gastric ventriculus smooth muscle (M) adjacent the thick serosa (S). Masson's trichrome stain. Barr $=25 \mu \mathrm{m}$.

\section{ACKNOWLEDGEMENTS}

Financial support from Fundação de Amparo à Pesquisa do Estado de São Paulo.

\section{REFERENCES}

BACHA, W.J.; BACHA, L.M. Color atlas of veterinary histology. 2.ed. Philadelphia: Lippincott Williams \& Wilkins, 2000. 318p.

BAILEY, T.A. et al. Comparative morphology of the alimentary tract and its glandular derivatives of captive bustards. Journal of Anatomy, v.191, p.387-398, 1997.

BANKS, W.J. Histologia veterinária aplicada. 2.ed. São Paulo: Manole, 1992. 629p.

BAUMEL, J.J. et al. Handbook of avian anatomy: nomina anatomica avium. 2.ed. Cambridge: Nuttall Ornithological Club, 1993. 779p.

BENNETT, T.; COBB, J.L.S. Studies on the avian gizzard: Morphology and innervation of the smooth muscle. Z Z Zell-forsch Mikrosk Anat, v.96, p.173-185, 1969.

CHIKILIAN, M.; DE SPERONI, N.B. Comparative study of digestive system of three species of tinamou. I. Crypturellus tataupa, Nothoprocta cinerascens, and Nothura maculosa (aves: Tinamidae). Journal of Morphology, v.228, p.77$88,1996$.

DYCE, K.M. et al. Anatomia das aves. In: DYCE, K.M., et al. Tratado de anatomia veterinária. 2.ed. Rio de Janeiro: Guanabara Koogan,1996. p.631-650.
GEORGE, L.L. et al. Histologia comparada. 2.ed. São Paulo: Roca, 1998. 286p.

MACARI, M. et al. Anatomia e histologia funcional do trato digestivo. In: FUNDAÇÃO APINCO de Ciência e Tecnologia Avícolas. Fisiologia da digestão e absorção das aves. Campinas: APINCO, 1994. p.1-18.

MELVIN, J.; REECE, W.O. Dukes - Fisiologia dos animais domésticos. 11.ed. Rio de Janeiro: Guanabara Koogan, 1996. p.390-397.

NICKEL, R. et al. Anatomy of the domestic birds. Berlim: Verlag Paul Parey, 1977. p.41-50.

"SAS"- STATISTICS ANALYSIS INSTITUTE. User's guide. North Caroline, 1999. 426p.

SATO, Y. et al. An occurrence of stomach impaction in ostriches (Struthio camelus) on a farm in Zambia associated with high mortality. Journal of Veterinary Medical Science, v.56, n.4, p.783-784, 1994.

SISSON, S. ; GROSSMAN, J.D. Anatomia dos animais domésticos. 5.ed. Rio de Janeiro: Guanabara Koogan, 1986. $2000 \mathrm{p}$.

SUGANUMA, T. et al. Comparative histochemical study of alimentary tracts with special reference to the mucous neck cells of the stomach. American Journal of Anatomy, v.161, n.2, p.219-238, 1981.

TURK, D.E. The anatomy of the avian digestive tract as related to feed utilization. Poultry Science, v.61, p.1225$1244,1982$. 